\title{
PENGUKURAN KINERJA PADA KOPERASI KARYAWAN EKA SEDANA BERDASARKAN KONSEP BALANCE SCORECARD
}

\author{
I Putu Arya Dharmayasa \\ Jurusan Pendidikan Ekonomi \\ Pascasarjana FKIP \\ Universitas Sebelas Maret \\ Surakarata, Indonesoa \\ e-mail: aryadarmayasa4@gmail.com
}

\begin{abstract}
Abstrak
Tujuan dari penelitian ini adalah untuk untuk menilai kinerja Koperasi Karyawan Eka Sedana berdasar konsep Balanced Scorecrd serta memberikan kontribusi kepda manajemen tentang bagaimana penilaian kinerja koperasinya. Jenis data yang digunakan adalah data kualitatif dan kuantitatif. Metode pengumpulan data dalam penelitian ini menggunakan metode wawancara, kuesioner, dan dokumentasi. Sumber data yang digunakan yaitu data primer dan data skunder, yang dianalisis dengan tektik analisis kualitatif dan kuantitatif dengan mengukur perspektif keuangan, perspektif pelanggan, perspektif bisnis internal, perspektif pertumbuhan dan pembelajaran. Hasil penelitian menunjukan bahwa kinerja Koperasi Karyawan Eka Sedana dilihat dari perspektif keuangan kurang baik sehingga harus ditinggkatkan lagi , namun dilihat dari perspektif non keuangan baik. Saran yang diberikan kepada menejemen akan lebih meningkatkan lagi kinerja keuangan dan non keuangan untuk keberlangsungan koperasi ( going concern).
\end{abstract}

Kata Kunci : Balanced Scorecard, perspektif keuangan, perspektif pelanggan, perspektif bisnis internal, perspektif pertumbuhan dan pembelajaran

\begin{abstract}
Tujuan dari penelitian ini adalah untuk untuk menilai kinerja Koperasi Karyawan Eka Sedana berdasar konsep Balanced Scorecrd serta memberikan kontribusi kepda manajemen tentang bagaimana penilaian kinerja koperasinya. Jenis data yang digunakan adalah data kualitatif dan kuantitatif. Metode pengumpulan data dalam penelitian ini menggunakan metode wawancara, kuesioner, dan dokumentasi. Sumber data yang digunakan yaitu data primer dan data skunder, yang dianalisis dengan tektik analisis kualitatif dan kuantitatif dengan mengukur perspektif keuangan, perspektif pelanggan, perspektif bisnis internal, perspektif pertumbuhan dan pembelajaran. Hasil penelitian menunjukan bahwa kinerja Koperasi Karyawan Eka Sedana dilihat dari perspektif keuangan kurang baik sehingga harus ditinggkatkan lagi , namun dilihat dari perspektif non keuangan baik. Saran yang diberikan kepada menejemen akan lebih meningkatkan lagi kinerja keuangan dan non keuangan untuk keberlangsungan koperasi ( going concern).
\end{abstract}

Kata Kunci : Balanced Scorecard, perspektif keuangan, perspektif pelanggan, perspektif bisnis internal, perspektif pertumbuhan dan pembelajaran

\section{PENDAHULUAN}

Dalam era globalisasi sekarang ini, perkembangan dunia bisnis yang semakin competitive dan turnbulence menyebabkan suatu perusahaan diharuskan melakukan perbaikan di segala bidang agar tetap menjadi pelaku pasar dalam jangka waktu panjang dengan produk yang berdaya saing yang tinggi. Kondisi ini mengharuskan manajemen agar dapat 
meningkatkan strategi yang mampu bertahan dan berkembang dalam persaingan.

Para pelaku ekonomi berupaya membangun perekonomian yang pada akhirnya turut serta meningkatkan kesejahteraan rakyat. Tiga pilar ekonomi nasional yaitu Badan Usaha Milik Negara (BUMN), swasta dan koperasi berupaya melakukan usaha seperti di sektor jasa keuangan maupun pembiayaan. Badanbadan usaha tersebut memberikan berbagai jasa keuangan maupun pembiayaan untuk membantu serta memfasilitasi masyarakat dan sektor Usaha Mikro, Kecil dan Menengah (UMKM). Sesuai UU No. 20 Tahun 2008, bahwa sektor UMKM perlu diberdayakan sebagai bagian internal ekonomi rakyat agar mampu tumbuh dan berkembang menjadi usaha yang tangguh dan mandiri. Sehingga masing-masing badan usaha tersebut berkompetisi dalam penyaluran dananya untuk membantu sektor UMKM maupun masyarakat.

Perkembangan badan-badan usaha tersebut masih dihadapkan pada berbagai permasalahan baik yang bersifat internal maupun eksternal yang kurang kondusif. Adapun permasalahan tersebut yaitu: (1) aspek infrastruktur dan kelembagaan, (2) efesiensi operasional, (3) belum optimalnya pemberdayaan usaha, (4) strategi manajemen yang kurang tepat, (5) rendahnya kemampuan Sumber Daya Manusia, (6) permodalan, dan (7) terbatasnya akses pasar (Wijono dalam Ashari).

Peran strategis yang dimainkan pelaku-pelaku ekonomi yang baik BUMN, swasta maupun koperasi menuntut adanya penyusunan kebijakan dan pengembangan strategi agar tetap menjadi pelaku pasar dalam jangka panjang sehingga lebih optimal dalam pembangunan nasional. Ketiganya dituntut memiliki daya saing secara internal, regional, nasional maupun lokal.

Untuk mengatasi berbagai kendala tersebut, diperlukan adanya evaluasi kinerja melalui pengukuran kinerja yang handal (realible). Pengukuran kinerja merupakan hal esensial bagi perusahaan. $\mathrm{Hal}$ ini dikarenakan pengukuran kinerja dapat digunakan untuk menilai keberhasilan suatu perusahaan serta penyusunan strategi bisnis yang tepat. Menurut Ciptani (2000) dijelaskan bahwa pengukuran kinerja pada organisasi digunakan untuk melakukan koordinasi antara para manajer dengan tujuan dari masing-masing bagian nantinya akan memberikan kontribusi terhadap kemajuan dan keberhasilan perusahaan dalam mencapai sasarannya.

Metode pengukuran kinerja yang selama ini banyak digunakan baik pada sektor swasta maupun publik adalah pengukuran tradisional, yang hanya menekankan pada aspek finannsial saja. Sedangkan apabila diukur hanya dari aspek financial saja tidak mampu mencerminkan kinerja organisasi yang sesungguhnya.

Metode pengukuran kinerja yang dianggap tepat mengatasi kendalakendala secara menyeluruh pada lembaga keuangan mikro saat ini yaitu balance scorecard. Balance scorecard merupakan sebuah konsep pengukuran kinerja yang diperkenalkan oleh Roberts S. Kaplan \& David P. Norton (2000:22) sebagai metode pengukuran kinerja komprehensif yang tersusun dalam empat persepektif yaitu finansial, pelanggan, proses bisnis internal, serta pembelajaran dan pertumbuhan. Balance scorecard mampu menejermahkan visi, misi, dan strategi suatu organisasi ke dalam tujuan operasional dan ukuran kinerja baik kinerja finansial maupun non finansial.

Menurut Imelda balance scorecard dapat membantu organisasi publik dalam mengontrol keuangan dan mengukur kinerja organisasi. Saat ini, metode balance scorecard banyak digunakan sebagai alat pengukuran kinerja pada organisasi bisnis (profit seeking organization). Masih jarang implementasi balance scorecard pada organisasi publik (public organization) bahkan organisasi dengan karakteristik khsusus seperti koperasi (Imelda,2004).

Menurut Undang-Undang Nomor 25 Tahun 1992 Tentang Perkoperasian, dijelaskan bahwa koperasi adalah badan usaha yang bersangkutan orang seorang atau badan hukum koperasi dengan melandaskan kegiatannya berdasarkan prinsip sekaligus sebagai gerakan ekonomi 
rakyat yang berdasar atas asas kekeluargaan.

Koperasi merupakaan salah satu dapat dijadikan menempatkan diri sebagai salah satu kekuatan ekonomi. Kekuatan ekonomi lain yang sejajar dan berada di tengah gejolak perekonomian semakin lama semakin tampak bersifat kompetitif. Gagasan ini diperlukan suatu tekad untuk merombak organisasi yang sering kali dinggap berbentuk sosial, menjadi suatu kejadian ekonomi yang cukup tangguh.

Adanya koperasi yang sebenarnya sesuai dengan jiwa bangsa Indonesia justru mengalami perkembangan yang jauh dari harapan. Koperasi yang dianggap sebagai anak kandung dan tulang punggung ekonomi kerakyatan justru hidupnya timbul tenggelam. Pemerintah telah berjuang keras untuk menghidupkan dan memberdayakan koperasi di tengahtengah masyarakat. Begitu banyak kemudahan yang diperoleh oleh badan hukum koperasi melalui berbagai fasilitas, namun tidak banyak mengubah kehidupan koperasi itu sendiri. Hal ini dikarenakan oleh kepengurusan dan pengelolaan koperasi yang kurang profesional. Memang tidak dipungkiri bahwa ada sebagian koperasi yang masih tetap eksis di tengah masyarakat (Darmawi, 2005).

Namun kenyataannya dinamika ekonomi dan persaingan usaha menjadi tantangan besar bagi koperasi dalan menjalankan usahanya. Dalam era globalisai, koperasi harus bersaing dengan perusahaan-perusahaan global yang memiliki berbagai keunggulan dalam memutarkan roda bisnisnya. Paradigma masyarakat selama ini bahwa swasta dianggap paling efesien, produktif dan manajemen yang baik. BUMN dianggap perusahaan yang memiliki hak monopoli, birokratis, dan kurang efesien. Sedangkan koperasi dianggap sebagai badan usaha yang dimiliki pribadi, modal dan kapasitas usaha kecil, tidak dikelola dengan baik serta kurang berkembang. Sejauh ini, koperasi memang belum bisa berkembang pesat dibandingkan dengan pelaku-pelaku ekonomi lain seperti BUMN maupun swasta. Hal ini dikarenakan koperasi masih dihadapkan pada masalah kinerjanya yang belum optimal. Berbagai aspek permodalan yang masih kecil, kurangnya penguasaan teknologi mutakhir, keterampilan yang sederhana, lemahnya kemampuan manajemen, serta kurangnya dukungan pemerintah masih menjadi problema koperasi.

Untuk dapat bertahan dalam iklim persaingan usaha, koperasi harus terus melakukan konsolidasi intern yaitu mengusahakan kebangkitan koperasi agar dapat menjalankan peranannya dalam kehidupan perekonomian. Kepercayaan harus terus ditingkatkan dengan menumbuhkan koperasi sebagai badan usaha yang sehat, layak dan berorientasi pada kepentingan anggota. Untuk itu koperasi harus mampu meningkatkan daya saingnya seperti meningkatkan kemampuan manajemen, permodalan, penguasaan teknologi mutakhir serta keterampilan yang tinggi untuk menangani berbagai aktivitas usahanya (dalam Buletin Koperasi Edisi Juli/Agustus/September /1991). Seperti dipaparkan oleh Menteri Negara Koperasi dan Usaha Kecil dan Menengah (UKM) pada acara "Puncak Peringatan Hari Koperasi ke-63 tanggal 15 Juli 2010", koperasi diharapkan mampu meningkatkan kinerjanya sehingga menjadi kekuatan ekonomi rakyat yang mandiri, kreatif dan inovatif untuk mewujudkan kesejahteraan rakyat.

Koperasi Karyawan Eka Sedana yang selanjutnya disingkat dengan Kopkar "Eka Sedana" adalah Koperasi yang didirikan pertama kali tanggal 31 Januari 1960 dengan nama Perkumpulan Koperasi Simpan/Pinjam beranggotakan Buruh Listrik PLN Singaraja, selanjutnya dalam perkembangannya Koperasi mengalami Perubahan Anggota Dasar sebanyak 2 (dua) kali yaitu yang pertama pada tanggal 18 Agustus 1988 melalui keputusan RAT telah disepakati menjadi Koperasi Pegawai Negeri Eka Sedana dan perubahan yang kedua pada tanggal 31 Maret 1977 juga melalui kesepakatan RAT berubah menjadi Koperasi Karyawan Eka Sedana dengan Anggota Pegawai PT.PLN (Persero) Area Bali Utara beserta Karyawan Alih Daya (Outsourching) yang berbeda di wilayah kerja PLN Area Bali Utara beserta unit-unit dibawahnya (rayon-rayon) yang beralamat di Jalan Udayana Nomor 27 A Singaraja Bali. 


\begin{abstract}
Untuk mengetahui kinerja Koperasi Karyawan Eka Sedana secara keseluruhan perlu digunakan suatu metode yang dapat mengukur kinerja Koperasi Karyawan Eka Sedana bukan dari aspek keuangannya saja melainkan juga aspek-aspek non keuangan. Metode yang dianggap dapat memenuhi keinginan untuk menilai kinerja organisasi/perusahaan secara keseluruhan adalah balanced scorecard. Dimana konsep ini berusaha menyeimbangkan aspek keuangan dengan aspek non keuangan (Rindayani, dkk, 2015). Konsep balanced scorecard merupakan salah satu sarana untuk mengkomunikasikan persepsi strategis dalam suatu perusahaan secara sederhana dan mudah dimengerti oleh berbagai pihak dalam perusahaan, terutama pihak-pihak organisasi yang akan merumuskan strategis perusahaan. Dengan metode ini diharapkan pengukuran kinerja tidak hanya pada aspek keuangan saja melainkan juga aspek lainnya yaitu perspektif pelanggan, perspektif bisnis internal, perspektif pertumbuhan dan pembelajaran (Rijayana \& Paradita, 2014). Berdasarkan pendahuluan di atas maka tujuan dari penelitian ini adalah untuk mengukuran kinerja pada koperasi karyawan eka sedana berdasarkan konsep balance scorecard.
\end{abstract}

\section{METODE}

Jenis penelitian ini adalah penelitian kuantitatif dengan pendekatan deksriptif. Menurut arikunto (2002), tujuan dari penelitian komperatif adalah untuk menentukan dan membandingkan serta menggambarkan persamaan maupun perbedaan tentang suatu variabel tertentu dalam suatu penelitian, dan penelitian ini, peneliti menggambarkan dan membandingkan kondisi kinerja Koperasi Karyawan Eka Sedana.

Populasi yang di gunakna dalam penelitian ini adalah nasabah Koperasi Karyawan Eka Sedana yang berjumlah 200 orang digunakan untuk menilai kepuasan nasabah.

Penentuan jumlah sampel dalam penelitian ini ditentukan dengan menggunakan rumus Slovin yaitu: $\mathrm{n}=$

(Husein, 2003)

\section{Keterangan :}

$\mathrm{n}$ : ukuran sampel

$\mathrm{N}$ : ukuran populasi

e : Batas kesalahan

Berdasarkan rumus di atas untuk jumlah nasabah pada tahun 2014 sebesar 200 orang dengan tingkat kesalahan 10\% didapatkan jumlah sampel sebanyak 66,66 kemudian dibulatkan menjadi 67 orang.

$\mathrm{n}=$

Metode pengumpulan data yang digunakan dalam penelitian ini adalah: wawancara, kuisioner dan dokumentasi, sedangkan jenis data yang digunkan dalam penelitian ini yaitu: Data primer adalah data yang didapat dari sumbernya ( Hadi,1997). Data primer dalam penelitian ini berupa hasil jawaban respnden mengenai kepuasan nasabah Koperasi Karyawan Eka Sedana, Data Sekunder adalah data yang diperoleh secara tidak langsung, berupa keterangan yang ada hubungannya dengan penelitian yang sifatnya melengkapi atau mendukung data primer ( Hadi,1997). Data sekunder dalam penelitian ini berupa laporan RAT Koperasi Karyawan Eka Sedana periode 2016-2017.

Untuk mengetahui kondisi keuangan dan non keuangan perbandingan kinerja pada Koperasi Karyawan Eka Sedana digunakan suatu alat balanced scorecard, yang mengukur atau mengidentifikasikan perbandingan kinerja perusahaan yaitu analisis kuantitatif.

Analisis kuantitatif yaitu mengklarifikasikan kemudian menghitung, membandingkan, menganalisis data yang ada menggunakan bantuan rasio-rasio atau pertimbangan antara suatu jumlah tertentu dalam satuan-satuan hitung. Analisis menggunakan Balance score card menggunakan beberapa perspektif yaitu : Pertama (1) Perspektif Keuangan yang digunakan untuk melihat seberapa jauh keberhasilan yang dicapai oleh koperasi Karyawan Eka Sedana dapat dilihat pada tingkat kesehatan dari sisi keuangan. Analisis keuangan ini menunjukkan 
hubungan antara unsur-unsur dalam laporan keuangan.

Rasio likuiditas digunakan untuk menunjukkan kemampuan koperasi Karyawan Eka Sedana dalam membayar segala kewajiban jangka pendek. Semakin besar rasio likuiditasnya maka semakin baik karena menunjukkan kemampuan koperasi dalam memenuhi segala kewajiban jangka pendeknya. Tolak ukur yang digunakan untuk mengukur tingkat likuiditas koperasi Karyawan Eka Sedana adalah current ratio dengan rumus :

Analisis ROE digunakan untuk melihat koperasi Karyawan Eka Sedana dalam mengembalikan modal sendiri yang diinvestasikan yaitu dengan membandingkan keuangan dengan modal sendiri. Semakin tinggi rasio ROE maka semakin baik.

(4)

(5)

Kedua (2) Perspektif Pelanggan memiliki beberapa bagaian antara lain Profitabilitas Anggota yaitu untuk mengukur seberapa besar keuntungan yang berhasil diraih perusahaan dari peran serta anggota dalam kegiatan koperasi (Ali, 2002).

(6)

Tingkat Kesejahteraan Anggota untuk mengukur seberapa besar tingkat kesejahteraan anggota atas keikutsertaan anggota dalam koperasi (Ali, 2002). Tolak ukur yang digunakan adalah : Persentase SHU yang dibagikan :

Peningkatan Jumlah SHU yang dibagikan :

(9)

Tingkat Kepuasan Nasabah untuk menghitung rata-rata kepuasan nasabah dengan memberikan nilai pada jawaban kuisioner sesuai tingkat kepuasan yang dirasakan. Nilai yang diberikan adalah : Sangat Puas diberikan skor 5, Puas diberikan skor 4, Cukup puas diberikan skor 3, Tidak puas diberikan skor 2 dan Sangat tidak puas diberikan skor 1

Ketiga (3) Perspektif Bisnis Internal terdiri dari beberapa bagaian yaitu Operasi sebagai tolak ukur pada tahap operasi adalah dengan mengukur proses operasi persetujuan kredit dan simpanan dengan menggunakan MCE (Manufacturing Cycle Eficiency) semakin baik MCE jika angka rasio mendekati 1 , karena waktu yang terbuang untuk memeriksa dan memproses berkurang dan kemampuan koperasi menanggapi permintaan anggota koperasi dengan segera dapat terlaksana (Kaplan dan Norton, 2000).

Keempat (4)Layanan Pasca Penjualan untuk mengukur tingkat keterlibatan anggota dalam upaya meningkatkan aktivitas koperasi Karyawan Eka Sedana. Semakin besar tingkat partisipasi anggota maka semakin baik karena semakin banyak anggota yang ikut terlibat dalam upaya peningkatan aktivitas koperasi (Ali, 2002).

Kelima (5) Perspektif Pertumbuhan dan Pembelajaran terdri dari beberapa bagaian yaitu Rasio Perputaran Karyawan atau Retensi Karyawan

(13)

System untuk menganalisis kepatuhan informasi pencatatan pada koperasi Karyawan Eka Sedana dengan Kriteriakriteria reliabel, accuracy, dan timely (Ali, 2002). Penyelenggaraan Pendidikan Perkoperasian untuk mengetahui frekuensi penyelenggaraan pendidikan tahun 2016 dibandingkan dengan frekuensi penyelenggaraan pendidikan pada tahun 2017 (Ali, 2002). Turnover Piutang untuk mengukur tingkat kesadaran para anggota 
dan non anggota untuk membayar piutang. Semakin cepat piutang koperasi tersebut dikumpulkan maka semakin baik karena proses penyelenggaraan pendidikan koperasi mampu meningkatkan kesejahteraan anggota dan non anggota dalam membayar piutang dan pinjamannya. Tolak ukur dengan rumus :

\section{HASIL DAN PEMBAHASAN Hasil}

Penulis menggunakan skala (rating scale) yaitu stape, scale yang merupakan skala yang menilai objek yang diteliti diantara angka-angka yang ditentukan (Sekaran, 2008).

\section{Tabel 1 Penentuan Kriteria Rating Scale}

Tabel 2 Pengukuran Kinerja Koperasi Karyawan Eka Sedana Berdasarkan Konsep

\begin{tabular}{cc}
\hline Skor & Nilai \\
\hline-1 & Kurang \\
0 & Cukup \\
1 & Baik \\
\hline
\end{tabular}

Dalam hal ini nilai yang diperoleh adalah -1 sampai dengan 1. Skala ini merupakan skala yang paling sering digunakan dalam penelitian terdahulu untuk mengukur tingkat "baik", "cukup", atau "kurang", sehingga dianggap cukup reliabilitas. Asumsi yang digunakan untuk penelitian ini adalah kinerja dari masing-masing tolak ukur.

\section{Balanced Scorecard}

\begin{tabular}{|c|c|c|c|c|}
\hline & \multicolumn{2}{|c|}{ Tahun } & \multirow{2}{*}{ Skor } & \multirow{2}{*}{$\begin{array}{c}\text { Hasil } \\
\text { Pengukuran }\end{array}$} \\
\hline Balanced Scorecard & 2016 & 2017 & & \\
\hline
\end{tabular}

\section{Perspektif Keuangan:}

Rasio Likuiditas
Analisis ROE
Rasio Solvabilitas
Analisis LDR

Perspektif Pelanggan:

Retensi Anggota

Meraih Anggota

Profitabilitas Anggota

Kesejahteraan Anggota:

- Presentase SHU

- Peningkatan Jumlah SHU

Tingkat Kepuasan Nasabah:

- Pelayanan Menabung

- Pelayanan Kredit

\section{Perspektif Bisnis Internal:}

\section{Operasi}

Layanan Pasca Penjualan

$\begin{array}{rrrc}1,43 & 1,25 & -1 & \text { Kurang } \\ 0,04 \% & 0,05 \% & 1 & \text { Baik } \\ 60,93 \% & 52,20 \% & -1 & \text { Kurang } \\ 92,46 \% & 133,19 \% & 1 & \text { Baik }\end{array}$

$\begin{array}{cccc}106,22 \% & 100 \% & -1 & \text { Kurang } \\ 0,06 \% & 0 \% & -1 & \text { Kurang } \\ 0 \% & 0 \% & 0 & \text { Cukup }\end{array}$

$\begin{array}{llll}257.480 & 359.035 & 1 & \text { Baik }\end{array}$

$\begin{array}{llll}257.480 & 359.035 & 1 & \text { Baik } \\ 14,37 \% & 131,27 \% & 1 & \text { Baik }\end{array}$

Baik

Baik

Baik

$0,02 \% \quad 0,03 \% \quad 1 \quad$ Baik


Perspektif Pembelajaran dan Pertumbuhan:

Perputaran Karyawan

System

Pendidikan Perkoperasian

Turnover Piutang

$\begin{array}{cccc}0 \% & 0,06 \% & -1 & \text { Kurang } \\ - & - & 1 & \text { Baik } \\ 2 & 4 & 1 & \text { Baik } \\ 0,83 \% & 0,50 \% & -1 & \text { Kurang }\end{array}$

\section{Pembahasan}

Perspektif Keuangan bisa dinilai dari beberapa hal yakni yang pertama Rasio Likuiditas jika dilihat dari perhitungan diatas, untuk tahun 2016 jumlah aktiva lancar sebanyak 1,43 kali utang lancar, atau setiap 1 rupiah utang lancar dijamin oleh 1,43 aktiva lancar atau 1,43:1 antara aktiva lancar dengan utang lancar. Untuk tahun 2017 jumlah aktiva 1,25 kali utang lancar, atau setiap 1 rupiah utang lancar dijamin oleh 1,25 aktiva lancar atau 1,25:1 antara aktiva lancar dengan utang lancar. Menurut current ratio dari tahun 2016 ke 2017 mengalami penurunan sebesar 0,18 yaitu 1,43 di tahun 2016 menjadi 1,25 di tahun 2017. Hal ini berarti kemampuan koperasi dalam memenuhi kewajiban jangka pendeknya dengan menggunakan aktiva lancar dikatakan kurang baik, sehingga harus meningkatkan aktiva lancar untuk bisa memenuhi kewajiban jangka pendeknya. Namun, mengukur kinerja manajemen, ukuran yang terpenting adalah rata-rata industri untuk perusahaan ynag sejenis (Kasmir,2013). Temuan ini mendukung penelitian Anifah (2009) pada BMT Kraton dan BMT Wonorejo Pasuruan yang menerangkan bahwa Current Ratio dari periode 20032007 mengalami penurunan. Kondisi ini menjelaskan bahwa BMT memiliki utang lancar yang semakin bertambah dari jumlah aktiva lancar menurun. Kedua Analisis ROE Jika dilihat dari perhitungan diatas, ROE Koperasi Karyawan Eka Sedana mengalami peningkatan sebesar 0,01 yaitu 0,04 di tahun 2016 menjadi 0,05 di tahun 2017. Hal ini berarti koperasi memanfaatkan modal yang dimilikinya secara efektif untuk meningkatkan jumlah SHU yang diperoleh. Temuan ini mendukung penelitian Wahyuni (2011) pada PT. Semen Bosowa bahwa Return On Equity untuk tahun 2009 mengalami peningkatan sebesar $7,54 \%$ sedangkan untuk tahun 2010 meningkat sebesar $16,57 \%$. Salah satu faktor yang menyebabkan peningkatan ROE karena pada tahun 2008 perusahaan mengalami keuntungan yang menyebabkan peningkatan laba bersih pada tahun 20092010. Ketiga Rasio Solvabilitas jika dilihat dari perhitungan diatas, untuk tahun 2016 rasio solvabilitas sebesar $60,95 \%$ pendanaan koperasi dibiayai dengan hutang. Artinya, bahwa Rp 100 pendanaan koperasi Rp 60,95 dibiayai dengan hutang dan $\mathrm{Rp}$ 39,05 disediakan oleh anggota koperasi. Untuk tahun 2017 rasio solvabilitas sebesar $52,20 \%$ pendanaan koperasi dibiayai dengan hutang. Artinya, bahwa Rp 100 pendanaan koperasi Rp 52,20 dibiayai hutang dan $R p$ 47,8 disediakan oleh anggota koperasi. Menurut rasio solvabilitas dari tahun 2016 ke tahun 2017 mengalami penurunan sebesar $8,75 \%$ yaitu $60,95 \%$ di tahun 2016 menjadi $52.20 \%$ di tahun 2017. Hal ini berarti kemampuan Koperasi Karyawan Eka Sedana dalam memenuhi seluruh kewajibannya dengan menggunakan total aktiva yang dimilikinya kurang.Temuan ini mendukung penelitian Triastuty (2004) pada Koperasi Sarana Bhakti Semarang dilihat dari rasio solvabilitasnya mengalami penurunan. Hal ini disebabkan karena adanya kenaikan jumlah aktiva yang tidak seimbang dengan kenaikan jumlah hutang, sehingga Koperasi Sarana Bhakti dalam memenuhi kewajibannya dengan menggunakan aktiva yang dimilikinya kurang. Keempat Analisis LDR Jika dilihat dari perhitungan diatas, LDR Koperasi Karyawan Eka Sedana mengalami peningkatan sebesar $41,45 \%$ yaitu $92,46 \%$ di tahun 2016 menjadi 133,19\% di tahun 2017. Hal ini berari jumlah kenaikan pinjaman lebih kecil dibandingkan jumlah simpana, sehingga Koperasi Karyawan Eka Sedana dalam menarik kembali kredit yang telah diberikannya dikatakan baik. 
Temuan ini mendukung penelitian Arum (2013) bahwa LDR pada Bank BTN Kantor Cabang Surabaya mengalami penurunan dari tahun 2010-2012. Penurunan ini disebabkan oleh peningkatan simpanan sebagai sumber pembiayaan yang lebih tinggi dari peningkatan kredit sebagai aset pada tahun 2011.

Perspektif Pelanggan juga dilihat dari berbagai hal: yang pertama adalah Kemampuan Kesejahteraan Mempertahankan Anggota/ Retensi Anggota dari perhitungan diatas Koperasi Karyawan Eka Sedana mengalami penurunan dalam kemampuan mempertahankan anggotannya, dimana penurunan pada tahun 2016 sampai 2017 yaitu $6,22 \%$. Hal ini membuktikan bahwa Koperasi Karyawan Eka Sedana telah memberikan pelayanan ynag kurang terhadap anggotanya.Temuan ini mendukung penelitian Triastuty (2004) pada Koperasi Sarana Bhakti dilihat dari kemampuan koperasi mempertahankan anggotanya mengalami penurunan. Hal ini membuktikan bahwa anggota benar-benar membutuhkan pelayanan yang diberikan Koperasi Sarana Bhakti Semarang.

Kedua Kemampuan Koperasi Meraih Anggota, Jika dilihat dari perhitungan diatas, akuisisi di tahun 2016 lebih baik daripada akuisisi di tahun 2017 yaitu di tahun terdapat 15 anggota baru sedangkan di tahun 2017 tidak terdapat anggota baru yang masuk. Dari hal tersebut menunjukkan kemampuan Koperasi Karyawan Eka Sedana dalam meraih anggota menurun. Temuan ini mendukung penelitian Arum (2013) pada Bank BTN Kantor Cabang Surabaya bahwa bank dalam mendapatkan nasabah dilihat dari persentase selama 3 tahun menurun. Menurunnya jumlah nasabah tabungan secara tidak langsung dipengaruhi oleh kinerja bauran pemasaran. Kebijakan bauran pemasaran yang tidak sesuai dengan kegiatan nasabah akan mendorong respon nasabah menjadi tidak puas.

$\begin{array}{ccc}\text { Ketiga } & \begin{array}{c}\text { Profitabilitas } \\ \text { perhitungan }\end{array} & \begin{array}{c}\text { Anggota } \\ \text { diatas, }\end{array}\end{array}$
profitabilitas dikatakan cukup. Hal ini berarti terdapat banyak anggota yang cukup memberikan keuntungan kepada koperasi dalam membangun usaha koperasi sehingga profitabilitas anggota Koperasi Karyawan Eka Sedana dikatakan cukup. Temuan ini mendukung penelitian Saraswati (2014) pada PDAM Kabupaten Buleleng bahwa presentase Profitabilitas Pelanggan dari tahun 2011-2012 dikatakan cukup. Hal ini berarti pelanggan cukup memberikan profit bagi perusahaan dan ini merupakan hal yang positif bagi perusahaan.

Keempat Tingkat Kesejahteraan Anggota yang pertama adalah Presentase SHU yang dibagikan. Dari perhitungan diatas perhitungan presentase SHU yang dibagikan Koperasi Karyawan Eka Sedana mengalami kenaikan sebesar 101.555 yaitu 257.480 di tahun 2016 menjadi 359.035 di tahun 2017. Dari hal tersebut SHU yang dibagikan kepada anggotanya dikatakan baik. Temuan ini mendukung penelitian Triastuty (2004) pada Koperasi Sarana Bhakti Semarang dilihat dari presentase SHU yang dibagikan mengalami kenaikan. Peningkatan jumlah SHU yang dibagikan, dari perhitungan diatas peningkatan SHU yang dibagikan Koperasi Karyawan Eka Sedana mengalami kenaikan sebesar $116,9 \%$ yaitu 14,37\% di tahun 2016 menjadi 133,27\% di tahun 2017. Dari hal tersebut peningkatan jumlah SHU dari periode sebelumnya ke periode sekarang dikatakan baik. Temuan ini mendukung penelitian Kholiffaturohmah (2011) pada KSU Mekar Surya Karanganyar bahwa rasio peningkatan SHU yang dibagikan mengalami kenaikan dari tahun ke tahun. Hal ini berarti Unit Simpan pinjam KSU Mekar Surya Karanganyar mampu meningkatkan SHUnya dengan baik.

Kelima Tingkat Kepuasan Nasabah yang pertama Pengukuran rata-rata tingkat kepuasan nasabah tentang pelayanan menabung, dari hasil perhitungan di atas, dapat diketahui bahwa rata-rata kepuasan nasabah tentang pelayanan menabung pada Koperasi Karyawan Eka Sedana adalah 4,11 yang artinya nasabah merasa puas terhadap pelayanan menabung dari Koperasi Karyawan Eka Sedana. Temuan ini mendukung penelitian Triastuty (2004) bahwa rata-rata kepuasan anggota tentang pelayanan menabung pada Koperasi Sarana Bhakti Semarang adalah sebesar 3,71 yang artinya anggota merasa puas 
terhadap Pelayanan Menabung yang ditampilkan oleh koperasi. Kedua Pengukuran rata-rata tingkat kepuasan nasabah tentang pelayanan kredit, dari hasil perhitungan diatas, dapat diketahui bahwa rata-rata tingkat kepuasan tentang kredit menabung pada Koperasi Karyawan Eka Sedana adalah sebesar 4,10 yang artinya nasabah merasa puas terhadap pelayanan kredit dari Koperasi Karyawan Eka Sedana. Temuan ini mendukung penelitian Triastuty (2004) bahwa rata-rata kepuasan anggota tentang pelayanan menabung pada Koperasi Sarana Bhakti Semarang adalah sebesar 4,03 yang artinya anggota merasa puas terhadap Pelayanan Kredit yang ditampilkan oleh koperasi.

Perspektif Bisnis Internal juga dilihat dari beberapa hal yakni, pertama Operasi, Berdasarkan perhitungan diatas proses pelayanan tabungan dan kredit Koperasi Karyawan Eka Sedana dapat dikatakan baik yaitu kurang dari 1 . Hal ini berarti waktu dalam proses tabungan dan kredit pada Koperasi Karyawan Eka Sedana tidak terbuang dalam pelayanannya.Temuan ini mendukung penelitian Triastuty (2004) bahwa proses pelayanan menabung dan kredit pada koperasi Sarana Bhakti dikatakan baik yaitu kurang dari 1. Hal ini berarti dalam memproses menabung dan kredit Koperasi Sarana Bhakti tidak menabung waktu banyak yang sia-sia untuk memenuhi kebutuhan para anggotanya.

Kedua Layanan Pasca Penjualan, berdasarkan perhitungan diatas jumlah anggota aktif dapat dikategorikan baik, dimana tejadi peningkatan pada tingkat rasio anggota yang aktif sebesar $0,01 \%$ dari tahun 2016 sebesar $0,02 \%$ menjadi $0,03 \%$ pada tahun 2017 . Peningkatan ini menunjukkan semakin banyak anggota yang ikut aktif berpatisipasi dalam menggunakan haknya untuk memberikan pendapat, saran maupun kritik yang membangun pada Koperasi Karyawan Eka Sedana.

Temuan ini mendukung penelitian Triastuty (2004) pada Koperasi Sarana Bhakti Semarang dimana terjadi peningkatan pada tingkat rasio anggota yang aktif berpatisipasi sebesar $2 \%$ dari 24\% pada tahun 2001 menjadi 26\% pada tahun 2002. Peningkatan ini menunjukkan semakin banyaknya anggota yang ikut aktif berpatisipasi.

Perspektif Pertumbuhan dan Pembelajaran yang pertama adalah Rasio Perputaran Karyawan/Retensi Anggota, jika dilihat dari perhitungan di atas adanya perubahan jumlah yang keluar di tahun 2017. Temuan ini mendukung penelitian Saraswati (2014) pada PDAM Kabupaten Buleleng bahwa Retensi Karyawan tidak mengalami perubahan di tahun 2010 sedangkan tahun 2012 adanya perubahan. Kedua System dari hasil penelitian diatas, system Koperasi Karyawan Eka Sedana telah mempergunakan sistem pencatatan akuntansi dengan baik. Hal ini dapat dilihat dari evaluasi informasi kepatuhan pencatatan data dengan kriteria akurat (accurancy), dapat dipercaya (reliabel), dan tepat waktu (timely). Temuan ini mendukung penelitian Triastuty (2004) bahwa dalam hal ini mengevaluasi informasi kepatuhan pencatatan data dengan kriteria akurat (accurancy), dapat dipercaya (reliabel), dan tepat waktu (timely). Selama periode tahun 2001 dan 2002 Koperasi Saran Bhakti Semarang telah mempergunakan sistem pencatatan akuntansi dengan baik. Ketiga Penyelenggaraan Pendidikan Koperasi, dalam penyelenggaraan pendidikan pada Koperasi Karyawan Eka Sedana di tahun 2016 karyawan Koperasi Karyawan Eka Sedana telah mengikuti 2 kali pelatihan dan lokakarya tentang perkoperasian. Sedangkan di tahun 2017 karyawan Koperasi Karyawan Eka Sedana telah mengikuti pelatihan dan lokakarya tentang perkoperasian. Dalam hal tersebut penyelenggaraan pendidikan perkoperasian mengalami peningkatan sehingga dikatakan baik. Namun penyelenggaraan pendidikan perkoperasian bagi karyawan sebaiknya ditingkatkan lagi guna untuk perkembangan koperasi. Temuan ini mendukung penelitian Triastuty (2004) pada Koperasi Sarana Bhakti Semarang bahwa pada tahun 2001 telah mengikuti 12 kali pendidikan, lokakarya dan pelatihan tentang perkoperasian yang diikuti oleh pengurus, karyawan maupun anggota koperasi, sementara pada tahun 2002 Koperasi Sarana Bhakti Semarang 
mengikuti 27 kali pendidikan, lokakarya da pelatihan tentang perkoperasian. Hal ini menunjukkan adanya peningkatan pada penyelenggaraan pendidikan perkoperasian pada Koperasi Sarana Bhakti Semarang. Keempat Turnover Piutang, jika dilihat dari perhitungan diatas penurunan sebesar 0,33 dari 0,83 pada tahun 2016 menjadi 0,50 pada tahun 2017. $\mathrm{Hal}$ ini berarti tingkat pengembalian piutang kepada Koperasi Karyawan Eka Sedana semakin lambat dari tahun ke 2016 ke tahun 2017. Temuan ini mendukung penelitian Triastuty (2004) bahwa terjadi penurunan pengembalian piutang sebesar 0,05 dari 0,53 pada tahun 2001 menjadi 0,48 pada tahun 2002. Hal ini berarti tingkat pengembalian piutang kurang karena tingkat pengembalian piutang semakin lambat. Berdasarkan hal tersebut dapat diketahui terjadi penurunan kesadaran para anggota untuk mengembalikan pinjamannya.

\section{PENUTUP \\ Simpulan}

Berdasarkan pembahasan yang telah diuraikan di atas, maka dapat ditarik simpulan mengenai penilaian kinerja pada Koperasi Karyawan Eka Sedana berdasarkan konsep Balanced Scorecard: Dilihat dari Perspektif Keuangan, Rasio Likuiditas dan Rasio Solvabilitas Koperasi Karyawan Eka Sedana dari tahun 2016 ke tahun 2014 mengalami penurunan. Sedangkan analisis ROE dan analisis LDR Koperasi Karyawan Eka Sedana mengalami peningkatan. Dilihar dari Perspektif Pelanggan, Retensi Anggota dan Meraih Anggota Koperasi Karyawan Eka Sedana dikategorikan kurang baik, dan untuk Profitabilitas Anggota Koperasi Karyawan Eka Sedana dikatakan cukup baik. Sedangkan Presentase SHU dan Peningkatan Jumlah SHU Koperasi Karyawan Eka Sedana dikategorikan baik. Dilihat dari Perspektif Bisnis Internal, Operasi dan Layanan Pasca Penjualan Koperasi Karyawan Eka Sedana dikategorikan baik. Dilihar dari Perspektif Pembelajaran dan Petumbuhan, Retensi Karyawan dan Turnover Piutang Koperasi Karyawan Eka Sedana dikategorikan kurang baik. Sedangkan System dan
Pendidikan Perkoperasian Koperasi Karyawan Eka Sedana dikategorikan baik.

\section{Saran}

Berdasarkan simpulan diatas, maka saran yang dapat diberikan kepada Koperasi Karyawan Eka Sedana mengenai penilaian kinerja berdasarkan konsep Balanced Scorecard sebagai berikut: Koperasi Karyawan Eka Sedana agar lebih meningkatkan lagi kinerja keuangan terutama untuk meningkatkan kesejahteraan anggotanya. Koperasi Karyawan Eka Sedana sebaiknya memperhatikan sisi non keuangan karena hal ini sangat mempengaruhi sisi keuangan koperasi dan juga keberlangsungan usaha koperasi (going concern) sebagai koperasi simpan pinjam.

\section{DAFTAR PUSTAKA}

Ali, M. 2002. Penerapan Balanced Scorecard Sebagai Tolak Ukur Penilaian Kinerja |Pada Badan Usaha Berbentuk Koperasi.Jurnal Universitas Paramadina. Vol 1 (3): 245-246

Arikunto, S. 2002. ProsedurPenelitian Suatu Pendekatan Praktek. Jakarta:Rinewka Cipta

Ciptani, Monika Kussetya. 2000. Balanced Scorecard Sebagai Pengukuran Kinerja Masa Depan: Suatu Pengantar. Jurnal akuntansi dan keuangan, Vol.2 (1)

Darmawi, Herman. 2005. Manajemen Risiko. Jakarta: Bumi Aksara

Hadi, N. 1997. Metodologi Research, Untuk penulisan Paper, Skripsi, Thesis, Desertasi. Yogyakarta: Andi Offiset

Imelda, R.H.N. 2004. Implementasi Balanced Scorecard Pada Organisasi Publik. Jurnal Akuntansi dan Keuangan Vol. 6 (2): 106-122

Kaplan, Robert S. \& David P. Norton. 2000. Balanced Scorecard: Menerapkan Strategi Menjadi Aksi. Jakarta: Erlangga

Rindayani, Darmawan, Purnamawati. 2015. Analisis Kinerja Perusahaan 
Berbasis Balance Scorecard (Studi

Kasus Pada PT. Bali Pawiwahan).

Jurnal Akuntansi Vol. 3 (1)

Umar, Husein.2003. Metodologi

Penelitian: Aplikasi dalam

Pemasaran. Jakarta: Gramedia

Pustaka Utama 